\title{
Effect of Drill and Game Training Methods on Dribbling Ability of Soccer Games
}

\author{
Darmansyah $^{1 *}$, Umar $^{1}$, Donie $^{1}$ \\ ${ }^{1}$ Faculty of Sport Science, Universitas Negeri Padang, Prof. Dr. Hamka, Padang, Indonesia \\ "Corresponding author. Email: saifanammar20@gmail.com
}

\begin{abstract}
The maim of the study was to determine the effect of drill and game method exercises on the dribbling ability of football games of extracurricular students of Arrummani Middle School, Tambang District, Kampar Regency. This was a quasi-experimental research. The population was 54 extracurricular students of Arrummani Middle School, Kampar District. The sampling technique used was cluster proportional sampling technique, in this case was 22 extracurricular students aged 14 years. The data was collected using dribbling tests before and after treatment. The results of the research and data analysis showed that (1) the form of drill method exercise had significant effect on improving the dribbling ability of football games of the students $\left(t_{\text {counted }} 8.43>t_{\text {tabel }} 1,81\right)$, (2) the form of game method exercises significantly affected the ability of dribbling at football game ( $\left.\mathrm{t}_{\text {counted }} 4.28>\mathrm{t}_{\text {tabel }} 1,81\right)$, (3) there was significant difference in the effect of drill and game method exercises in improving dribbling skills in football games $\left(t_{\text {counted }} 2.12>t_{\text {tabel }} 1,81\right)$. Based on the result above, it can be concluded that the hypothesis is accepted.
\end{abstract}

\section{Keywords: drill, game, dribbling football.}

\section{INTRODUCTION}

Football sports are very popular including in Indonesia. This can be seen by the many people, both men and women, love go to the soccer field. Some play football game to spend their leisure time, some just love to watch the match, while the rest are practicing to become professional soccer players.

To perform a well football match, there are some technical aspects demanded. Techniques are components of sports achievement that must be prepared as well as possible [1]. Good mastery of techniques will optimize the use of physical conditions. By having good techniques, the skills will be improved too.

" Individual skills can occasionally be shown at certain times [2]. However, we have never seen a football player who gets the score alone. However, individual skills must be well mastered to master the ball and make opportunities to score. This certainly must be balanced with a good training pattern, in this case the drill method training.

Drill methods are generally used to obtain a dexterity or skill from what has been learned. Drill is an action to improve skills and skills. Then the method of playing is carried out in the form of playing activities so that the training objectives can be achieved efficient and effective in a happy atmosphere despite discussing difficult or difficult matters. Then it is intended to build a dynamic atmosphere of training, full of enthusiasm. The characteristic of the game is to create an atmosphere of exercise that is fun but meaningful in doing the exercises. It can be done through sustainably applying the principles of training and loading exercises in carrying out the training program provided by the coach / coach. In addition to the drill method, another method that can be developed is the game method.

The game / play method is a form of playing technique by modifying the game. It is the development of forms of games that lead to the mastery of simple dribbling techniques of soccer, so that it is easy for them to understand and it facilitates students / athletes and trainers in the training process. If these two methods implemented properly, it is expected to increase the ability of player's dribbling.

Dribbling is a basic skill in football because all players must be able to master the ball while moving, standing, or preparing to make passes or shots. When players have mastered the ability to dribbling effectively, their contribution in the match will be enormous.

Based on the results of researcher observations conducted on Arrummani Middle School extracurricular students, there were several phenomena occurring in the field such as, students 'dribbling techniques were still unsatisfactory. It was seen when students dribbled the ball stiffly. Whereas, in doing dribbling, a player must be able to do dribbling in a moving, standing position, and be able to pass and pass the ball after dribbling.

This certainly needs some methods or techniques so that students 'dribbling skills are good, one solution is to provide some form of training methods (drill methods and game methods), so that students' dribbling techniques become better and more optimal. In addition to aspects of 
the training method, another aspect that needs to be considered is the provision of training programs.

\section{METHOD}

The method used in this study is quasi-experimental research. It is said that this research was an experimental research because this study will examine the cause and effect relationship of the independent variable on the dependent variable which is the effect of training (treatment).

The population in this study was all students who took part in the Arrummani Junior High School extracurricular activities in the District of Mine in Kampar Regency, totaling 54 people. The population is clearly described in the following table:

Table 1. Football Extracurricular Students.

\begin{tabular}{|l|l|l|}
\hline No & Age & male \\
\hline 1 & 13 & 17 \\
\hline 2 & 14 & 22 \\
\hline 3 & 15 & 15 \\
\hline \multicolumn{2}{|l|}{ Total Amount } & $\mathbf{5 4}$ \\
\hline
\end{tabular}

The sampling technique used in this study was cluster sampling technique which is a sampling technique performed on sampling units, where the sampling unit consists of one group (cluster) [4]. . In this study, researchers took samples of U-14 years.

After that, the sample was divided into two groups. The division of groups was done by ranking the results of the pre-test, then pairing them with an A-B-B-A (ordinal pairing) pattern in two groups of members each of the 11 male athletes.

The primary data in this study was taken directly and obtained from the person who conducted the predetermined experiment, while the secondary data is obtained from students' home teacher. The data was obtained from pre-test and post-test. The normality test aims to find out whether the sample was normally distributed or not.

The normality using used was Liliefors formula. Homogeneity tests were conducted to obtain information on whether the two sample groups had homogeneous variances or not [5]. Besides, T test was used to test the hypotheses. The $t$ test used was based on [6].

\section{RESULTS}

(1) The form of drill method training has a significant effect on improving the dribbling ability of the football game of extracurricular students at Arrummani Middle School, Tambang District, Kampar Regency $\left(\mathrm{t}_{\text {count }}=8.43>\right.$ $t_{\text {table }}=1.81$ ). (2) The form of game method training has significant effect to increase the dribbling skills in football games for extracurricular students at Arrummani Middle School in Tambang District, Kampar Regency ( $\mathrm{t}$ count $=$ 4.28> $\mathrm{t}_{\text {table }}=1.81$ ). (3) There are differences in drill method training and game method training in improving the dribbling skills of football games for extracurricular students at Arrummani Middle School in Tambang District, Kampar Regency $\left(\mathrm{t}_{\text {count }}=2.12>\mathrm{t}_{\text {table }}=1.81\right)$.

\section{Discussion}

Drill method training is a kind of exercise movement carrying a ball, herding ball from one point to another with the aim that the ball can be passed to playmates or immediately shot to the opponent's goal

The results of the study generally revealed the results of the dribbling ability of the extracurricular football game of Arrummani Middle School in Tambang District, Kampar Regency, after obtaining treatment in the form of drill training methods the improvement had a significant effect compared to before being given treatment.

This is in accordance with the opinion of the researchers that the dribbling ability of football can be improved through drill practice. It was also supported based on the results of statistical analysis the average value obtained by researchers who experienced an increase from the initial test amounted to 16.95 to 14.18 in the final test, based on the increase in the results of the initial hypothesis proposed in chapter II can be accepted empirically.

Hypothesis testing shows that $\mathrm{t}_{\text {-count }}$ was $8.43(\alpha$ 0.05) and $(\mathrm{dk})=10(0.975)$, then the value of $\mathrm{t}_{-}$table was 1.81 . Thus, $\mathrm{Ha}$ is accepted and $\mathrm{Ho}$ is rejected. Thus the hypothesis which stated "drill method training has a significant effect onimprovement in the dribbling ability of extracurricular football games at Arrummani Middle School in Tambang District, Kampar Regency " is accepted.

Based on the explanation above, we can conclude that training can improve the efficiency of some organs that are trained in the implementation of the exercise, so to improve the dribbling ability of soccer games can be given a game method training, this can be seen from the results of pre-test and post-test. The students test result was increased ever since they were treated by game method. It supported by hypothesis testing which shows that $\mathrm{t}_{\text {count }}=$ $4.28(\alpha=0.05)$ and $(\mathrm{dk})=10(0.975)$, then the $t_{-}$table value $=$ 1.81 . Thus, $\mathrm{t}_{\text {count }}(4.28)>\mathrm{t}_{\text {table }}(1.81)$.

Thus the hypothesis proposed is accepted by the truth empirically. So the game method exercises significantly towards improving the dribbling skills of football games for extracurricular students at Arrummani Middle School, Tambang District, Kampar Regency.

Nevertheless, there are differences in the results of the speed of students' time in dribbling, between the two exercises given. Drilling method training is better than the game method. This is supported based on the results of statistical analysis of average values obtained by researchers who experienced an increase from the final test using the form Drill method exercises amounted to 14.18, while the results of the final test using the game method training form amounted to 15.80. Hence, there are differences in the influence of drill and exercise method game methods on improving the dribbling ability of soccer games.

From the explanation above, it can be understood that the form of drill method training is more effective than the practice of game methods on increasing dribbling skills in soccer games and supported by Hypothesis testing. In 
other words, there are differences in the effect of drill method training and game method training in increasing the dribbling ability of extracurricular football games at Arrummani Middle School in Tambang District, Kampar Regency, this is because drill method training is a method given gradually, so students can understand each pattern given, while the game method is the method given by playing patterns, so students focus on the game.

\section{CONCLUSION}

Based on the findings above, hereby the researcher states that both method, drilling and game methods, significantly influence the dribble ability. Besides, the effect of drilling technique outnumbers the game methods. Thus, it suggested to football trainers to apply these two technique to improve the players skills.

\section{REFERENCES}

[1] Syafruddin, "Introduction to Training," Padang; FIK UNP Press, pp, 87-90. 2011.

[2] Irawadi, Hendri, "Physical Conditions and Measurements," Padang; UNP Press, pp, 65-78. 2011.

[3] Irmansyah, Johan, "The Effect of Decline Push Up and Standing Fore Arm Flexion Exercises on the Accuracy of Top Service at the Bolavoli Academy IKIP Mataram," Mataram; J. of Sports and Health Education. FPOK IKIP Mataram. Vol, 2 No, 1, pp, 410-414. Jan. 2016.

[4] Ministry of Youth and Sports "RI Law No.3 of 2005 concerning National Sports System," Jakarta; Ministry of Youth and Sports. 2005.
[5] Arikunto, Suharsim, "Research Procedures A Practice Approach,” Jakarta; Renika Cipta. 2016 